\title{
Effect of Inorganic and Organic Fertilizers on the Performance and Profitability of Grain Amaranth (Amaranthus caudatus L.) in Western Kenya
}

\author{
Richard O. Nyankanga (Corresponding author) \\ Department of Plant Science and Crop protection, University of Nairobi \\ P.O. Box 30197 - 00100, Nairobi, Kenya \\ Tel: 254-20-205-5129Ｅ-mail: richard.nyankanga@uonbi.ac.ke \\ Richard N. Onwonga \\ Department of Land Resource Management and Agricultural Technology \\ University of Nairobi, P.O. Box 30197 - 00100, Nairobi, Kenya
}

Francis S. Wekesa

Ministry of Agriculture, Kilimo House, P.O. Box 30028- 00100, Nairobi, Kenya

Dorothy Nakimbugwe

Dept. Food Science \& Technology, Makerere University

P.O. Box 7062 Kampala, Uganda

Dorothy Masinde

VEDCO, P. O. Box 1244, Kampala, Uganda

Johnny Mugisha

Dept. Agricultural Economics \& Agribusiness, Makerere University

P.O. Box 7062 Kampala, Uganda

Received: November 8, 2010

Accepted: November 26, $2010 \quad$ Online Published: December 1, 2011

doi:10.5539/jas.v4n1p223

URL: http://dx.doi.org/10.5539/jas.v4n1p223

\begin{abstract}
Protein malnutrition is a major cause of morbidity and mortality in developing countries where the cost and availability of animal protein remain prohibitive. Grain amaranth (Amaranthus caudatus $L$ ) has the potential to substitute expensive animal protein. Its production and consumption is however low in Kenya. Nitrogen is a key limiting element in grain amaranth production. This study investigated the effects of different rates of inorganic nitrogen and cattle manure on the growth and yield of grain amaranth over a period of two years. Inorganic fertilizer at the rate of $100 \mathrm{~kg} \mathrm{~N} / \mathrm{ha}$ significantly delayed flowering. Grain yield showed a linear response to inorganic and organic $\mathrm{N}$ application. Regression analysis projected the optimum inorganic fertilizer and manure application rates of $87.5 \mathrm{~kg} \mathrm{~N} / \mathrm{ha}$ and $9 \mathrm{t} / \mathrm{ha}$ respectively with yield of $1.84 \mathrm{t} / \mathrm{ha}$. The highest profitability was achieved at the optimum manure and fertilizer rates. The projected manure and inorganic fertilize rates may however not be affordable by the small-scale farmers. Thus a follow-up study to test the combined effect of inorganic and organic fertilizers is recommended.
\end{abstract}

Keywords: Manure, Grain yield, Gross margins; Inorganic nitrogen, Protein amaranth 


\section{Introduction}

There is widespread and severe protein malnutrition in Kenya and other developing countries due to poverty and inability of vulnerable groups to access adequate amounts of expensive animal protein foods to meet dietary requirements (WHO, 2004). Grain amaranth has the potential to substitute expensive animal protein because of its comparable protein quality and quantity (FAO/WHO/UNO, 1985; FAO, 2003). Despite its nutritional qualities, its production and consumption is still limited in Kenya. This is partly attributed to the fact that little research has been done to determine the best agronomic practices to maximize grain production and inherent low soil fertility. Furthermore, low and declining soil fertility due to continuous cultivation, soil erosion and nutrients losses through runoff and leaching is a serious problem in many parts of Kenya (Okalebo, 2002). About 30\% of increases in harvests by small-scale farmers in the third world in the last three decades is due to use of chemical fertilizers (Bunch, 1996). However, in view of their escalating prices, green manure crops, compost and animal manure are increasingly being used for soil fertility management (Bernick, 2008). In Kenya, only $25 \%$ of grain amaranth farmers use either inorganic or organic fertilizer albeit in quantities less than the recommended rates. The average grain yield of grain amaranth in Kenya is $0.5-1 \mathrm{t} / \mathrm{ha}$ compared to $2.5 \mathrm{t} / \mathrm{ha}$ to $3 \mathrm{t} / \mathrm{ha}$ achieved with optimal use of fertilizers (Bernick, 2008).

Fertility needs for grain amaranth production varies significantly depending on rainfall amounts and distribution (Mposi, 1999). Studies show that nitrogen is the most limiting nutrient under most environments (Pospisil et al., 2006). Phosphorous and potassium are only applied in soils that are especially deficient in these nutrients with the rate of $50 \mathrm{~kg}$ P/ha being considered optimum (Myers and Putnam, 1988; Ojo et al., 2007). There is limited information on soil fertility requirements for grain amaranth production in Kenya as the crop is relatively new. The current research was accordingly undertaken to investigate the appropriate levels of nitrogen fertilizer and manure application for enhanced grain amaranth production in Kenya.

\section{Research Methodology}

\subsection{Site description}

Field experiments were conducted during the short rain season of 2008 and the long rain season of 2009 at the Maseno University Research Farm (latitude N $0^{0} 1$ ' -S $0^{0} 12^{\prime}$ and latitude E $34^{0} 24^{\prime}-\mathrm{E}_{4} 4^{\circ} 47^{\prime}$ ), in Western Kenya. The rainfall distribution is bimodal with the long rains occurring from March to July and short rains from September to December (Jama et al., 1997). The area receives an annual average rainfall of $1750 \mathrm{~mm}$ and the temperature ranges from $15^{\circ} \mathrm{C}-31^{\circ} \mathrm{C}$ (Abednego et al., 2003). During the experimental period, $1672 \mathrm{~mm}$ annual rainfall was received in 2008 and $710.5 \mathrm{~mm}$ during the months of January-July, 2009. The mean temperature during the experimental period was $20^{\circ} \mathrm{C}$.

The major soil type of the area is classified as acrisols (FAO, 2003). The measured initial soil properties were: Moderate in total nitrogen $(0.13 \%)$, low Mehlich phosphorus (3.95 ppm), high potassium $(2.97 \mathrm{Cmol} / \mathrm{kg})$, moderate organic carbon $(1.37 \%)$ and moderately acidic $\left(\mathrm{pH}\right.$ water; 5.03 and $\mathrm{pH} 0.01 \mathrm{Cacl}_{2} ; 5.8$ ). Prior to the commencement of the field experiments, the experimental plots had been under fallow for a year.

\subsection{Experimental design and agronomic practices}

The experiment was laid out as randomized complete block design with three replications and conducted over two seasons. Land preparation was done using a tractor powered disc plough and harrow. The plot sizes were $5 \times 4 \mathrm{~m}$ with a footpath of 0.5 and $1 \mathrm{~m}$ between the plots and replicates, respectively. The treatments were inorganic fertilizer and cattle manure applied at the rates of $0,30,60$ and $100 \mathrm{~kg} \mathrm{~N} / \mathrm{ha}$, and $0,0.5,1.0,2.0$ and $3.0 \mathrm{t} / \mathrm{ha}$, respectively. Inorganic fertilizer was applied at half rate at planting in the form of Diammonium Phosphate (DAP 18:46:0) and the balance top dressed as Calcium Ammonium Nitrate (CAN 26\% N) six weeks after sowing. Manure was incorporated in the soil before planting. Grain amaranth was planted at a spacing of 30 x $60 \mathrm{~cm}$ using hand hoes. Weeding was done three times, 3, 6 and 9 weeks after sowing in both years.

\subsection{Data collection}

Plant height and inflorescence length were measured on five plants randomly sampled from the inner rows of each plot weekly starting 5 weeks after planting to harvesting. Days to $50 \%$ flowering were determined by averaging the period it took for half of the plants in each plot to flower. Days to harvest for each treatment were determined by the average period to physiological maturity. Dry matter was determined by destructive harvesting of 5 plants from the inner rows of each plot. The plants from each treatment were chopped and dried at $65^{\circ} \mathrm{C}$ for 48 hours in an oven. The destructive sampling was done at harvest to avoid changing plant population in the course of plant growth. Grain yield was measured by harvesting the inner rows and the grain threshed and dried to moisture content of $12-13 \%$ and then weighed for yield analysis. 


\subsection{Data analysis}

Data was subjected to Analysis of Variance using one way ANOVA, of Genstat statistical package (Lawes Agricultural Trust Rothamsted Experimental Station) and the differences in means compared by least significant difference at the $5 \%$ probability level. Regression analysis was done to determine the optimal application rates of inorganic fertilizer and cattle manure. Marginal Rate of Return was (MRR) used to determine the profitability of grain amaranth production. Sensitivity analysis was conducted to determine the effect of varying the rate of fertilizer, fertilizer price and grain yield on the MRR of grain amaranth.

\section{Results and discussion}

\subsection{Effect of fertilizer application on plant height and Inflorescence length}

Application of inorganic fertilizer and manure significantly $(p<0.05)$ improved crop growth as compared to the control (Figures 1 and 2). More rapid growth of grain amaranth was realized with use of chemical fertilizer compared to manure. This could be due to increased availability of soil nitrogen with application of inorganic fertilizer culminating into enhanced $\mathrm{N}$ uptake and hence faster growth. Release of nitrogen by manure however occurs slowly after mineralization.

These findings are in agreement with those of other researchers (Pang and Letey, 2000; Hartemink et al., 2000; Eghball et al., 2002) who found that while nitrogen supplied by inorganic fertilizer was readily available, the nitrogen supplied by manure was released slowly.

Inflorescence length increased with increasing application of fertilizer rates. The highest inflorescent length was achieved when inorganic fertilizer was applied at $100 \mathrm{~kg} \mathrm{~N} / \mathrm{ha}$ and manure applied at $3 \mathrm{t} / \mathrm{ha}$ (Figures 3 and 4). Inorganic fertilizer at the rate of $100 \mathrm{~kg} \mathrm{~N} / \mathrm{ha}$ significantly increased $(\mathrm{P}<0.05)$ days to $50 \%$ flowering compared to the lower $\mathrm{N}$ levels of 0,30 and $60 \mathrm{~kg} \mathrm{~N} / \mathrm{ha}$. The $50 \%$ flowering occurred after 57 days compared to the controls' 42 days. There was no significant $(\mathrm{P}<0.05)$ difference in days to $50 \%$ flowering across the manure application rates.

Increased levels of inorganic fertilizer and manure could have led to increased availability and uptake of nitrogen which promoted vegetative growth and prolonged the period to flowering and physiological maturity. Similar findings on the effect of fertility on amaranth growth have also been reported (Materechera and Medupe, 2006; Mhlontlo et al., 2007; Myers, 1998; Spetter and Thompson, 2007; Bruce and Philipe, 2008).

\subsection{Effect of fertilizer on grain amaranth yield and harvest index}

Fertilizer application significantly $(\mathrm{p}<0.05)$ improved dry matter production and yield of grain amaranth (Table 1). The rate of increase in grain yield rose steadily as the rate of nitrogen was raised from $0 \mathrm{~kg} / \mathrm{ha}$ to $100 \mathrm{kgN} / \mathrm{ha}$ to the optimum level of $87.5 \mathrm{~kg} \mathrm{~N} / \mathrm{ha}$. Similarly, the grain yield continued to increase at an increasing rate as the rate of manure was raised to the optimum level of $2.65 \mathrm{t} / \mathrm{ha}$ (Figure 5).

The harvest index was not significantly affected by the rate of fertilizer application (Table 1), showing that there was no change in biomass partitioning with application of the different rates of inorganic fertilizer. Gunda et al. (2005) also found no significant difference in the harvest index when $\mathrm{N}$ was applied at the rates of up to $120 \mathrm{~kg}$ N/ha.

Grain yield showed a linear response to inorganic fertilizer and manure application (Figures 5 and 6). When inorganic fertilizer was used (Figure 5), the yield response followed the regression equations $y=0.019 x+0.29$ $\left(R^{2}=0.988\right)$ and $y=0.018 x+0.23\left(R^{2}=0.980\right)$ in 2008 and 2009 respectively. In the first year, the grain yield increased to $1.96 \mathrm{t} / \mathrm{ha}$ with application of $90.0 \mathrm{~kg} \mathrm{~N} / \mathrm{ha}$. In the second year, the grain yield rose to $1.71 \mathrm{t} / \mathrm{ha}$ with the application of $85.0 \mathrm{~kg} \mathrm{~N} / \mathrm{ha}$. Over the two years, the grain response to inorganic fertilizer showed an optimum inorganic fertilizer application rate of $87.5 \mathrm{~kg} \mathrm{~N} / \mathrm{ha}$ with an optimum grain yield of $1.84 \mathrm{t} / \mathrm{ha}$.

Similarly, when manure was used (Figure 6), the grain yield showed a linear response, $y=0.0181 \mathrm{x}+0.01$ $\left(\mathrm{R}^{2}=0.869\right)$ and $\mathrm{y}=0.227 \mathrm{x}+0.01\left(\mathrm{R}^{2}=0.923\right)$ in 2008 and 2009 respectively. The grain yield increased to 0.67 and $0.79 \mathrm{t} / \mathrm{ha}$ with application of manure at the rate of $3 \mathrm{t} / \mathrm{ha}$ in 2008 and 2009 respectively. Regression analysis showed that the optimum grain yield of $1.84 \mathrm{t} / \mathrm{ha}$ obtained with application of inorganic fertilizer could be obtained with a manure rate of $10.0 \mathrm{t} / \mathrm{ha}$ and $8.0 \mathrm{t} / \mathrm{ha}$ in 2008 and 2009 respectively. The optimum manure rate was therefore projected as $9.0 \mathrm{t} / \mathrm{ha}$ being the average for the two years.

These results are in agreement with the findings of Elbehri et al. (1993), Myers (1998) and Bruce and Philip (2008) who reported a linear response of grain amaranth yield to $\mathrm{N}$ fertilization. The increase in grain yield as fertilizer application rates increased could have been due to increased plant growth, flowering and grain filling. 
This responsiveness of grain amaranth yield to nitrogen fertilization is comparable to the findings of other researchers (Myers, 1996; Jefferson Institute, 1999; Bruce and Philipe, 2008).

The increase in grain yield obtained with application of $30 \mathrm{~kg} \mathrm{~N} / \mathrm{ha}$ of inorganic fertilizer and $1 \mathrm{t} / \mathrm{ha}$ of manure compared to the control appears drastic. This could be attributed to the inherent low fertility of the soil at the experimental site. According to Myers (1996), Jefferson Institute (1999) and O'Brien and Price (1983) only 45 to $90 \mathrm{~kg} \mathrm{~N} / \mathrm{ha}$ was required to reach maximum yield of $2 \mathrm{t} / \mathrm{ha}$ with the lower rate used following soybeans or other legumes. Kauffman and Weber (1990) also found grain yield to increase when nitrogen was applied at rates up to $90 \mathrm{~kg} \mathrm{~N} / \mathrm{ha}$, to double at $100 \mathrm{~kg} \mathrm{~N} / \mathrm{ha}$ and reduce at higher rates.

When grain amaranth was grown using manure, better grain yields were obtained in the second year across all manure rates. This is attributable to the slow release of nutrients from organic sources and hence available for prolonged periods of time. For this reason, the yields in the first year with application of manure were low compared to inorganic fertilizer application. In the second year however the yields were higher in all the manure treated plots implying sufficient nitrogen release, coupled with nitrogen carryover from the previous season, with resultant enhanced uptake and consequently higher crop yields. This is in agreement with the findings of Stute and Posner (1995) and Onwonga et al. (2008) who reported that use of manures could help build soil fertility and increase $\mathrm{N}$ supply for the succeeding crops.

\subsection{Effect of fertilizer on grain amaranth profitability}

The marginal rate of return (MRR) increased with increase in the rate of inorganic fertilizer up to the optimum rate before decreasing with further increase in fertilization (Figure 7). In the first year, the marginal rate of return increased with increase in the rate of inorganic fertilizer from 0 to $90.0 \mathrm{~kg} \mathrm{~N} / \mathrm{ha}$ and thereafter declined with further increase in the rate of fertilization. During the second year, the MRR increased with increase in the rate of fertilization from 0 to $85.0 \mathrm{~kg} \mathrm{~N} / \mathrm{ha}$ and thereafter decreased with increase in the rate of inorganic fertilizer (Figure 7). Averaged over the two years, the greatest MRR of 7.51 was achieved with application of inorganic fertilizer at the rate of $87.5 \mathrm{~kg} \mathrm{~N} / \mathrm{ha}$.

Similarly, the MRR increased with increase in the rate of manure application up to optimum rate of 10.0 and 8.0 t/ha in 2008 and 2009 respectively (Figure 8). In 2008, the MRR remained stable with increase in the rate of manure up to $2 \mathrm{t} / \mathrm{ha}$ before increasing steadily as the rate of manure increased to $3 \mathrm{t} / \mathrm{ha}$. The maximum MRR was projected to 6.81 at a manure rate of $10.0 \mathrm{t} / \mathrm{ha}$ in 2008. In 2009, the MRR increased steadily with increase in the rate of application of manure from 0 to $3 \mathrm{t} / \mathrm{ha}$. The MRR was projected to increase further with increase in the rate of fertilization up to a maximum of 8.44 at manure application rate of $8.0 \mathrm{t} / \mathrm{ha}$ (Figure 8). Averaged over the two years, the highest MRR of 7.63 would be achieved with application of manure at rate of $9.0 \mathrm{t} / \mathrm{ha}$, a rate also obtained through regression analysis. The marginal rate of return decreased with increase in fertilizer and manure prices (Figures 9 and 10). The marginal rate of return increased with increase in grain yield following application of inorganic and organic fertilizer at various rates (Figures 11 and 12).

\section{Conclusion}

Application of inorganic fertilizer and manure were found to improve the growth, yield and MRR of grain amaranth. Based on the results of regression analysis and sensitivity analysis, the optimum inorganic fertilizer and manure application is estimated at of $87.5 \mathrm{~kg} \mathrm{~N} / \mathrm{ha}$ and $9.0 \mathrm{t} / \mathrm{ha}$, respectively. Better marginal rates of return were realized with higher grain yields indicating that grain amaranth production would be profitable with increased application of inorganic fertilizer and cattle manure. However, the projected manure rates of 9 tons/ha and $87.5 \mathrm{~kg} \mathrm{~N} / \mathrm{ha}$ may not be affordable by the small-scale farmers. This therefore calls for a follow-up study on an integrated approach to soil fertility management through a balanced use of chemical fertilizers in combination with organic manures.

\section{Acknowledgement}

This study was funded by the Lake Victoria Research Initiative (VicRes). We thank the Ministry of Agriculture, Kenya, University of Nairobi, Makerere University and VEDCO for their support

\section{References}

Abednego, K., Qureish, N., Bashir, J. (2003). Annotated Inventory of Agroforestry Related Work in western Kenya (1987 - 2003). World Agroforestry Centre, Nairobi.

Akanbi, W.B., Akande, M.O., Baiyewu, R.A, Akinfasoye, J.O. (2000). The effect of maize stover compost and Nitrogen fertilizer on growth, yield and Nitrogen uptake of Amaranth. Journal of Agricultural Research, 1(1), 6-15. 
Bernick, K. (2008). Manure Makes Sense. Corn and Soybean digest. Penton Media, Inc. (2009), city or town 7900 International Drive, Suite 300 Minneapolis, MN 55425.

Bruce, G., Philippe, S. (2008). Evaluation of Management Practices for Grain Amaranth Production in Eastern Canada. Agronomy Journal, 100,344-351. http://dx.doi.org/10.2134/agrojn12007.0189

Bunch, R. (1996). Green manure crops. Amaranth to Zai Holes, Ideas for Growing Food under Difficult Conditions. ECHO, 1996, 397 p.

Eghball, B., Wienhold, B.J., Gilley, J.E., Eigenberg, R.A. (2002). Mineralization of manure nutrients. Journal of Soil and Water Conservation, 57(6), 470-473.

Elbehri, A., Putnam, D.H., Schmitt, M. (1993). Nitrogen Fertilizer and Cultivar Effects on Yield and Nitrogen-Use Efficiency of Grain Amaranth. Agronomy Journal, 85,120-128. http://dx.doi.org/10.2134/agronj1993.00021962008500010023x

FAO. (2003). Map of World Soil Resources.1:25 000 000. FAO Rome.

FAO/WHO/UNO. (1985). Energy and protein requirements. WHO Tech. Report, Serial. no. 724.

Gunda, S.E., Hans-Peter, K., Markus, K., Walter, A. (2005). Yield and nitrogen utilization efficiency of the pseudocereals amaranth, quinoa, and buckwheat under differing nitrogen fertilization. European Journal of Agronomy, 22, 95-100. http://dx.doi.org/10.1016/j.eja.2003.11.002

Hartemink, A., Buresh, J., Bodegom, P.M., Braun, A.R., Jama, B., Janssen, B.H. (2000). Inorganic fertilizeritrogen dynamics in fallows and maize on an Oxisol and Alfisol in the highlands of Kenya. Geoderma, 98, 11-33. http://dx.doi.org/10.1016/S0016-7061(00)00072-0

Heineman, A.M., Otieno, H.J., Mengich, E.K., Amadalo, B.A. (1997). Growth and yield of eight agroforestry tree species in line plantings in western Kenya and their effect on maize yields and soil properties. Forest Ecology and Management, 91,103-135. http://dx.doi.org/10.1016/S0378-1127(96)03885-6

Jama, B., Rob, A.S., Buresh, R.J. (1997). Agronomic and economic evaluation of organic and inorganic sources of phosphorus in Western Kenya. Agronomy Journal, 89, 597-604. http://dx.doi.org/10.2134/agronj1997.00021962008900040010x

Jefferson Institute. (1999). Grain Amaranth: The Lost Crop of the Americas. Amaranth Production Manual. University of Nebraska Extension Service.

Kauffman, C.S., Weber, L.E. (1990). Grain amaranth. p. 127-139. In: J. Janick and J.E. Simon (eds.), Advances in New Crops, Timber Press, Portland.

Materechera, S. A., Medupe, M. L. (2006). Effects of cutting frequency and nitrogen from fertilizer and cattle manure on growth and yield of leaf amaranth (Amaranthus hybridus) in a South African semi-arid environment. Biological Agriculture \& Horticulture, 23(3), 251-262.

Mhlontlo, S., Muchaonyerwa, P., Mnkeni, P.N.S. (2007). Effects of sheep kraal manure on growth, dry matter yield and leaf nutrient composition of a local amaranthus accession in the central region of the Eastern Cape Province, South Africa. South African Water Research Commission, Report. Vol.33, No.3, Special Edition.

Mohsen, S. and Majid, R. (2008). Modeling of Soil Available Phosphorus Based on Soil organic Carbon. ARPN Journal of Agricultural and Biological Science, Vol. 3, No. 5\&6, September-November, 2008.

Mposi, M.S. (1999). Vegetable amaranth improvement for South Africa. Australian New Crops Newsletter, Issue No 11, January 1999.

Myers, R. L. (1998). Nitrogen Fertilizer Effect on Grain Amaranth. Agronomy Journal, 90,597-602. http://dx.doi.org/10.2134/agronj1998.00021962009000050005x

Myers, R.L. (1996). Amaranth: New crop opportunity. p. 207-220. In: J. Janick (ed.), Progress in New Crops. ASHS Press, Alexandria, VA.

Myers, R.L., Putnam, D. H. (1988). Growing Grain Amaranth as a Specialty Crop. Communication and Educational Technology Services, University of Minnesota Extension.

Niang, A., Amadalo, B., Gathumbi, S.M., Otieno, J.H., Obonyo, C., Obonyo, E. (1996). Agroforestry Research Networks for Africa (AFRENA) Project Maseno, Kenya progress report for September 1995 to September 1996. Rapport AFRENA Report. No. 110. KEFRI, KARI and ICRAF. 
O'Brien, G. K., Price, M. L. (1983). Amaranth: Grain \& Vegetable Type. Echo Technical Note. Durrance Rd, North Ft. Myers, FL 33917, USA.

Ojo, O.D., Kintomo, A.A., Akinrinde, E.A., Akoroda, M.O. (2007). Comparative Effect of Phosphorus Sources for Grain Amaranth Production. Communications in Soil Science and Plant Analysis, 38(1), 35-55. http://dx.doi.org/10.1080/00103620601093611

Okalebo, J.R., K.W. Gathua., P.L. Woomer. (2002). Laboratory methods of soil and plant analysis: A working manual (2nd ed) TSBF-CIAT and SACRED Africa, Nairobi, Kenya.

Olaniyi, J.O. (2007). Evaluation of Yield and Quality Performance of Grain Amaranth Varieties in the Southern Nigeria. Research Journal of Agronomy, 1(2), 42-45.

Onwonga, R. N., Lelei, J.J., Freyer, B., Friedel, J.K., Mwonga, S.M., Wandhawa, P. (2008). Low Cost Technologies for Enhancing N and P Availability and Maize (Zea mays L.) Performance on Acid Soils. World Journal of Agricultural Sciences, 4 (S), 862-873.

Pang, X.P., Letey, J. (2000). Organic farming: Challenge of timing nitrogen availability to crop nitrogen requirements. Soil Science Society of America Journal, 64,247-253. http://dx.doi.org/10.2136/sssaj2000.641247x

Spetter, J., Thompson, L. (2007). The revival of an ancient crop. LEISA Magazine, (23) 3, September 2007.

Stute, J.K., Posner, J.L. (1995). Synchrony between legume nitrogen release and corn demand in the upper Midwest. Agronomy Journal, 87, 1063-1069. http://dx.doi.org/10.2134/agronj1995.00021962008700060006x

WHO. (2004). Inheriting the world. The atlas of children's health and the environment.

Table 1. Effect of inorganic fertilizer and manure on yield and harvest index of grain amaranth in Western Kenya in 2008 and 2009 growing seasons

\begin{tabular}{|c|c|c|c|c|c|c|c|}
\hline & & \multicolumn{3}{|c|}{2008} & \multicolumn{3}{|c|}{2009} \\
\hline & & $\begin{array}{l}\text { Grain } \\
\text { yield } \\
(\mathrm{t} / \mathrm{ha})\end{array}$ & $\begin{array}{l}\text { Dry matter } \\
\text { yield } \\
(\mathrm{t} / \mathrm{ha})\end{array}$ & $\begin{array}{l}\text { Harvest } \\
\text { index }\end{array}$ & $\begin{array}{l}\text { Grain } \\
\text { yield } \\
(\mathrm{t} / \mathrm{ha})\end{array}$ & $\begin{array}{l}\text { Dry matter } \\
\text { yield } \\
(\mathrm{t} / \mathrm{ha})\end{array}$ & $\begin{array}{l}\text { Harvest } \\
\text { index }\end{array}$ \\
\hline \multirow{4}{*}{$\begin{array}{l}\text { Inorganic } \\
\text { fertilizer }\end{array}$} & $0 \mathrm{~kg} \mathrm{~N} / \mathrm{ha}$ & 0.29 & 0.74 & 0.28 & 0.23 & 0.65 & 0.26 \\
\hline & $30 \mathrm{~kg} \mathrm{~N} / \mathrm{ha}$ & 0.90 & 2.31 & 0.28 & 0.76 & 2.10 & 0.27 \\
\hline & $60 \mathrm{~kg} \mathrm{~N} / \mathrm{ha}$ & 1.55 & 3.61 & 0.30 & 1.47 & 3.71 & 0.28 \\
\hline & $100 \mathrm{~kg} \mathrm{~N} / \mathrm{ha}$ & 2.10 & 5.14 & 0.29 & 1.94 & 4.98 & 0.28 \\
\hline LSD $5 \%$ & & 0.573 & 1.220 & 0.044 & 0.347 & 1.012 & 0.059 \\
\hline \multirow[t]{5}{*}{ Manure } & $0 \quad \mathrm{t} / \mathrm{ha}$ & 0.01 & 0.024 & 0.29 & 0.01 & 0.025 & 0.29 \\
\hline & $0.5 \mathrm{t} / \mathrm{ha}$ & 0.05 & 0.120 & 0.29 & 0.05 & 0.122 & 0.29 \\
\hline & $1 \mathrm{t} / \mathrm{ha}$ & 0.11 & 0.280 & 0.28 & 0.13 & 0.300 & 0.30 \\
\hline & $2 \mathrm{t} / \mathrm{ha}$ & 0.25 & 0.560 & 0.31 & 0.39 & 0.890 & 0.30 \\
\hline & $3 \mathrm{t} / \mathrm{ha}$ & 0.67 & 1.560 & 0.30 & 0.79 & 1.810 & 0.30 \\
\hline LSD 5\% & & 0.093 & 0.179 & 0.051 & 0.210 & 0.531 & 0.042 \\
\hline
\end{tabular}




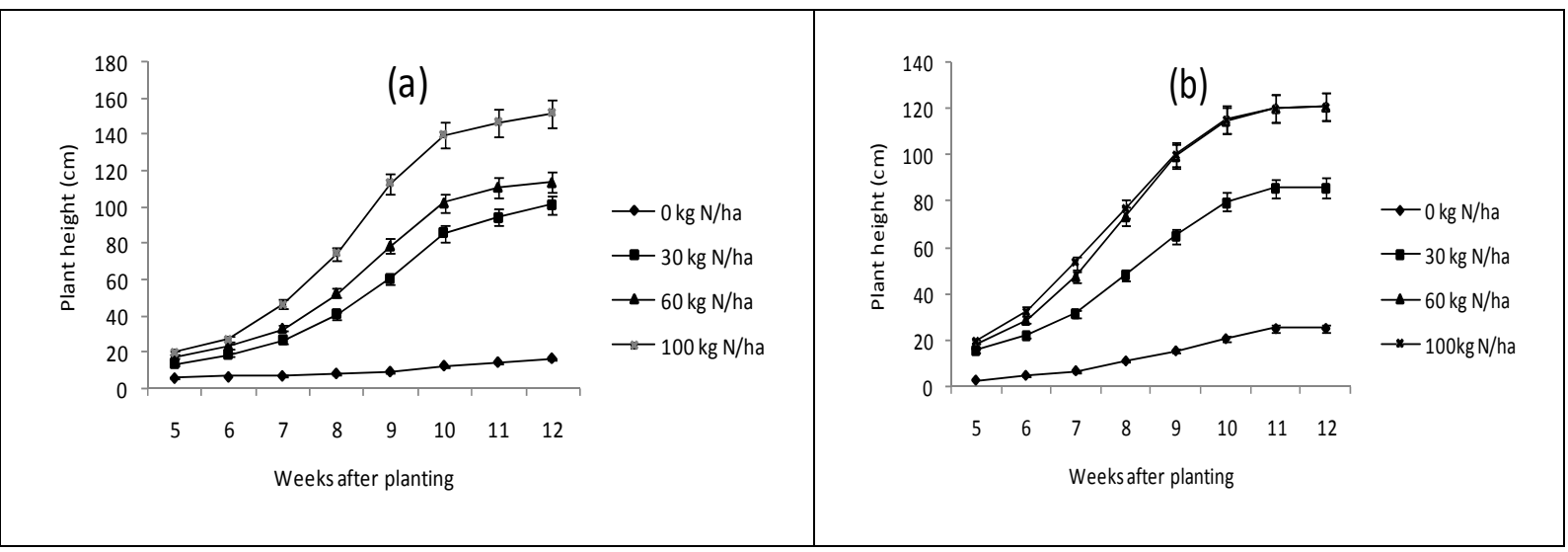

Figure 1. Effect of inorganic fertilizer on the height (cm) of grain amaranth in 2008 (a) and 2009 (b). Vertical bars show $\operatorname{LSD}_{0.05}$

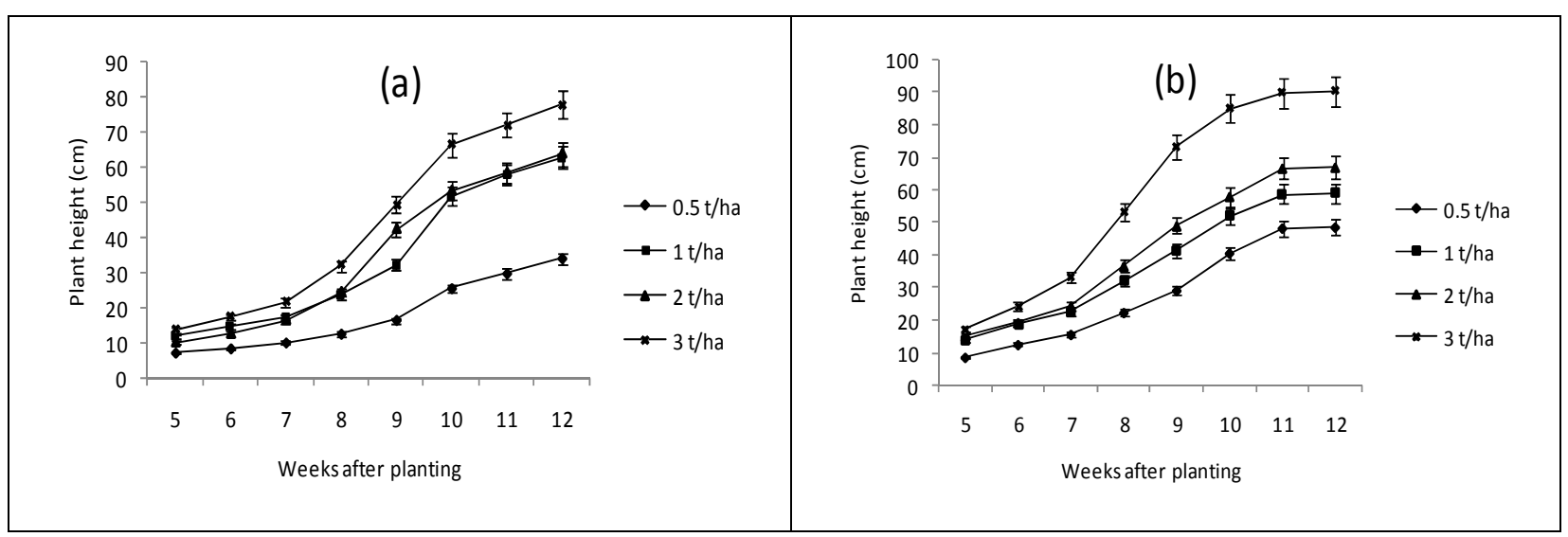

Figure 2. Effect of manure on the height (cm) of grain amaranth in 2008 (a) and 2009 (b). Vertical bars show

$$
\operatorname{LSD}_{0.05}
$$

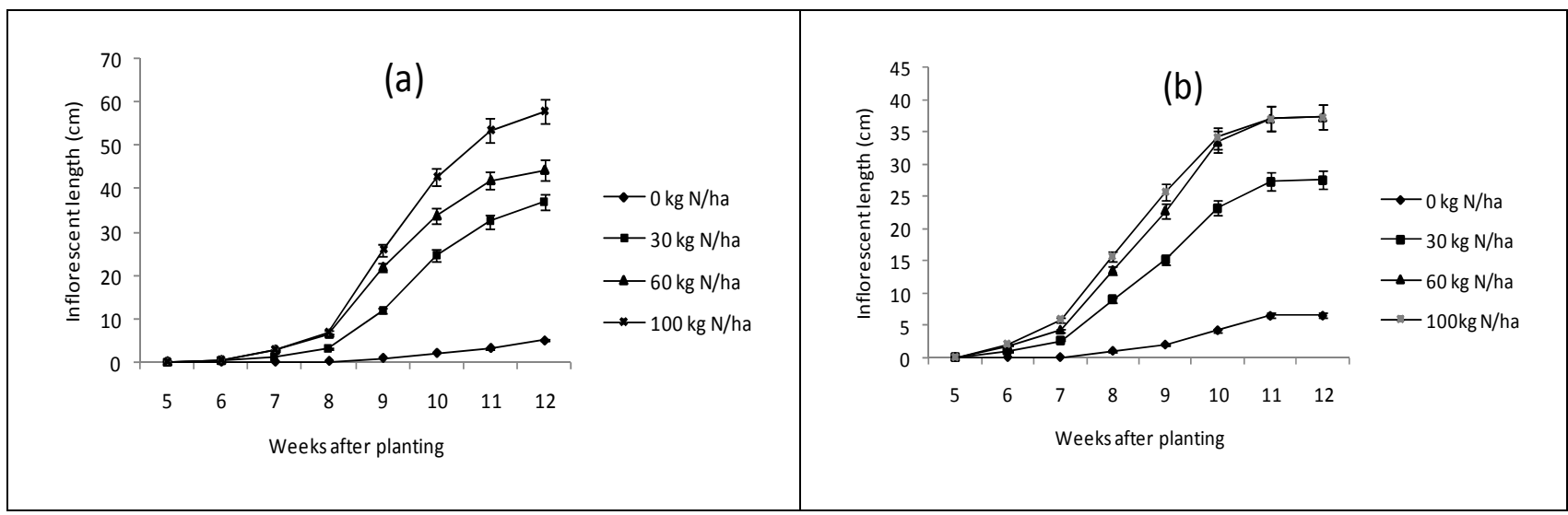

Figure 3. Effect of inorganic fertilizer on inflorescence length (cm) of grain amaranth in 2008 (a) and 2009 (b).

Vertical bars show $\operatorname{LSD}_{0.05}$ 


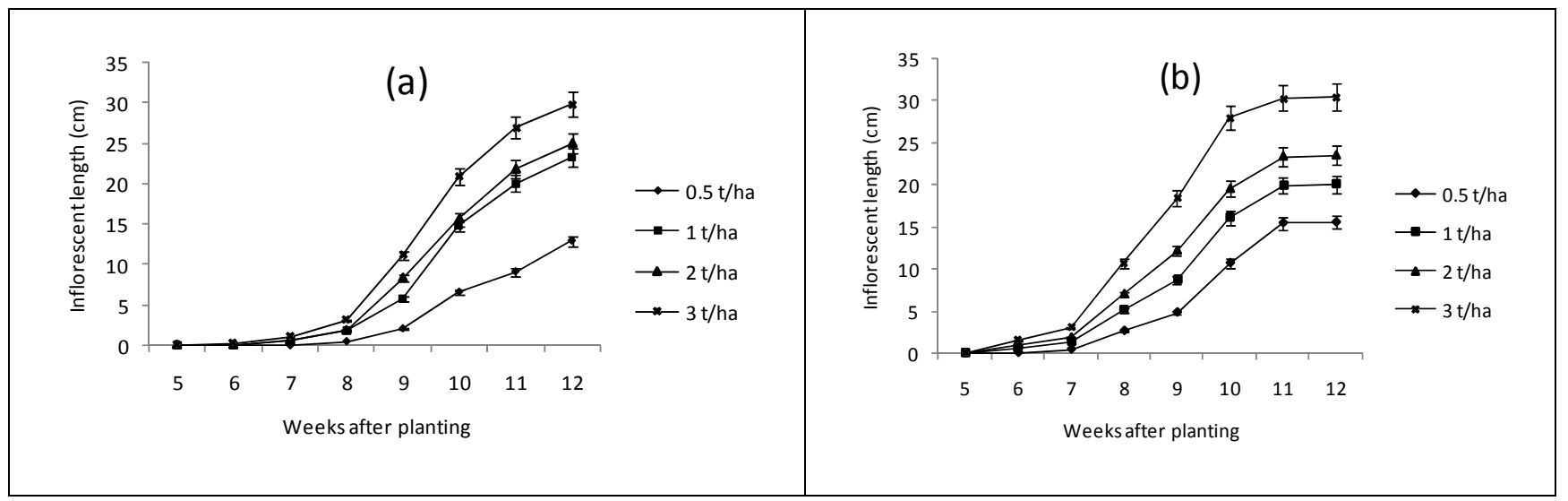

Figure 4. Effect of manure on inflorescence length (cm) of grain amaranth in 2008 (a) and 2009 (b). Vertical bars show LSD 0.05

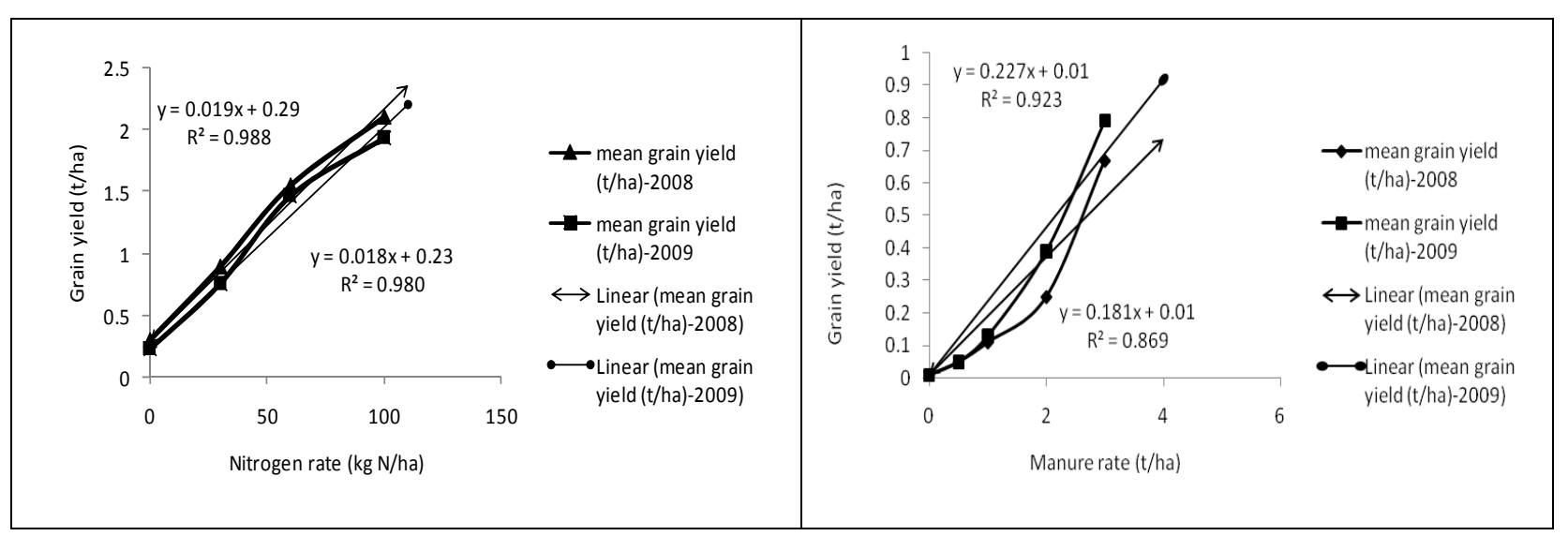

Figure 5. Regression analysis based on mean values of inorganic fertilizer and organic fertilizer on grain amaranth yield

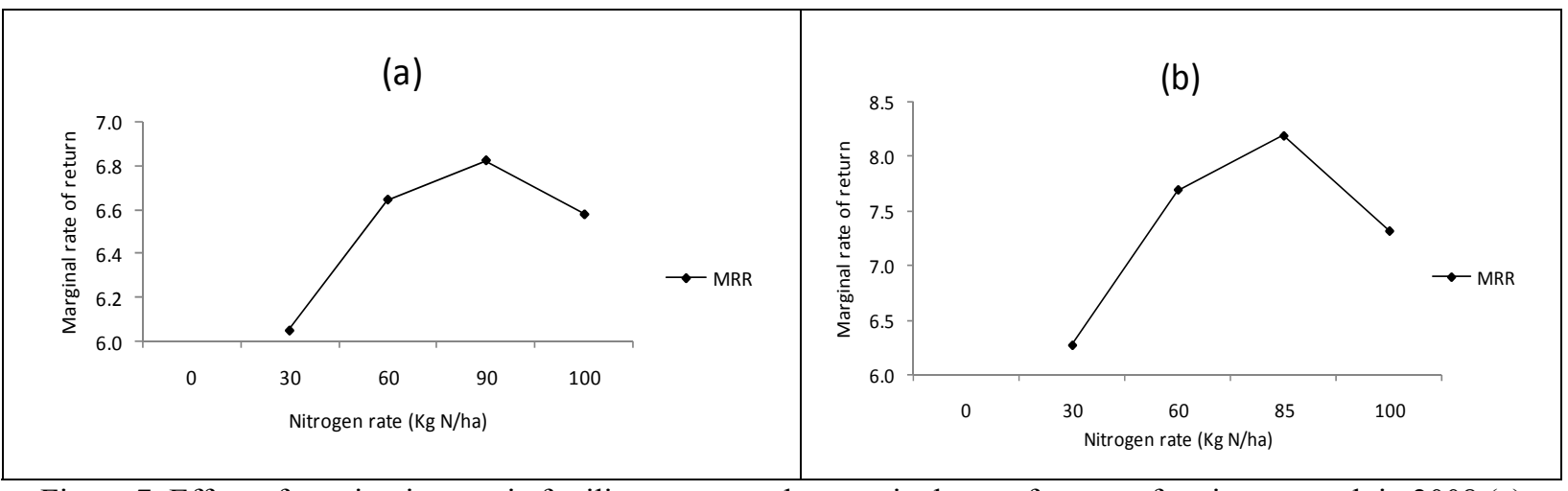

Figure 7. Effect of varying inorganic fertilizer rates on the marginal rate of return of grain amaranth in 2008 (a) and 2009 (b) 


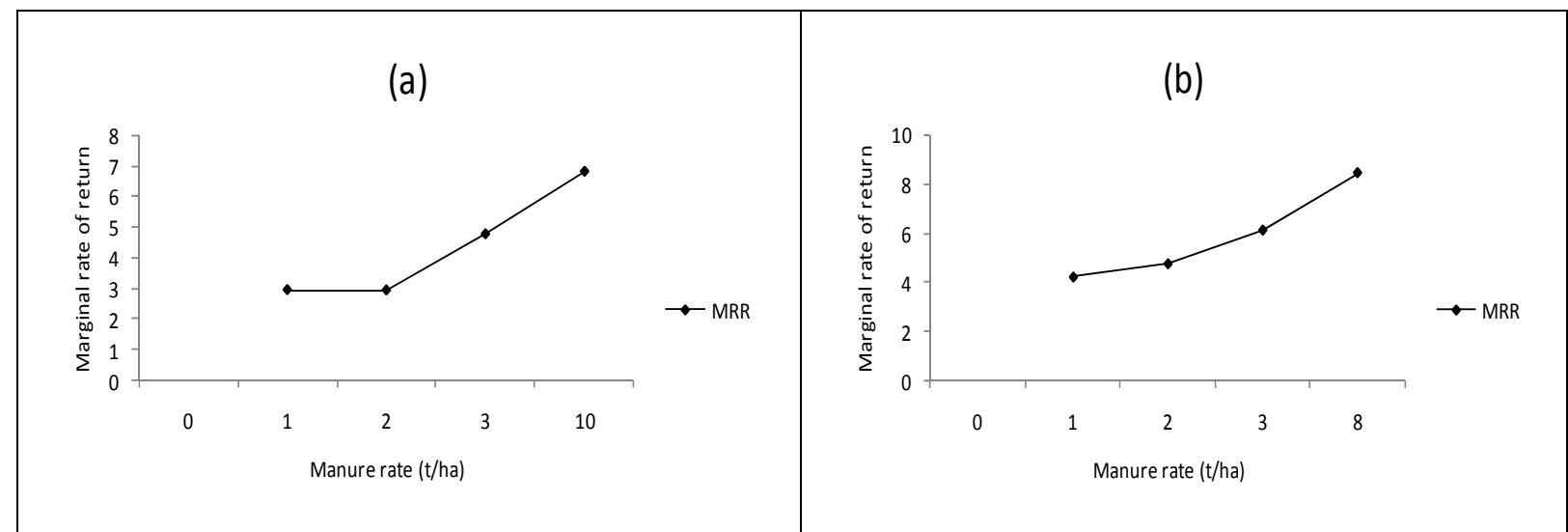

Figure 8. Effect of varying manure rates on the marginal rate of return of grain amaranth in 2008b (a) and 2009

(b)

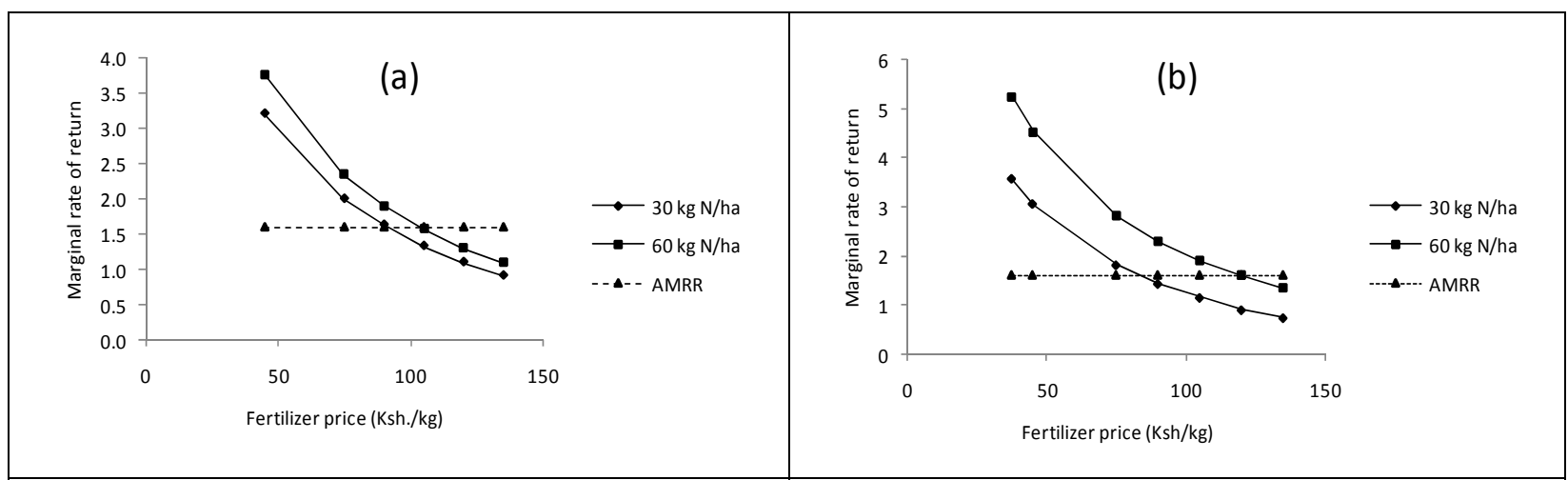

Figure 9. Effect of varying fertilizer price on the marginal rate of return of grain amaranth in 2008 (a) and 2009

(b)

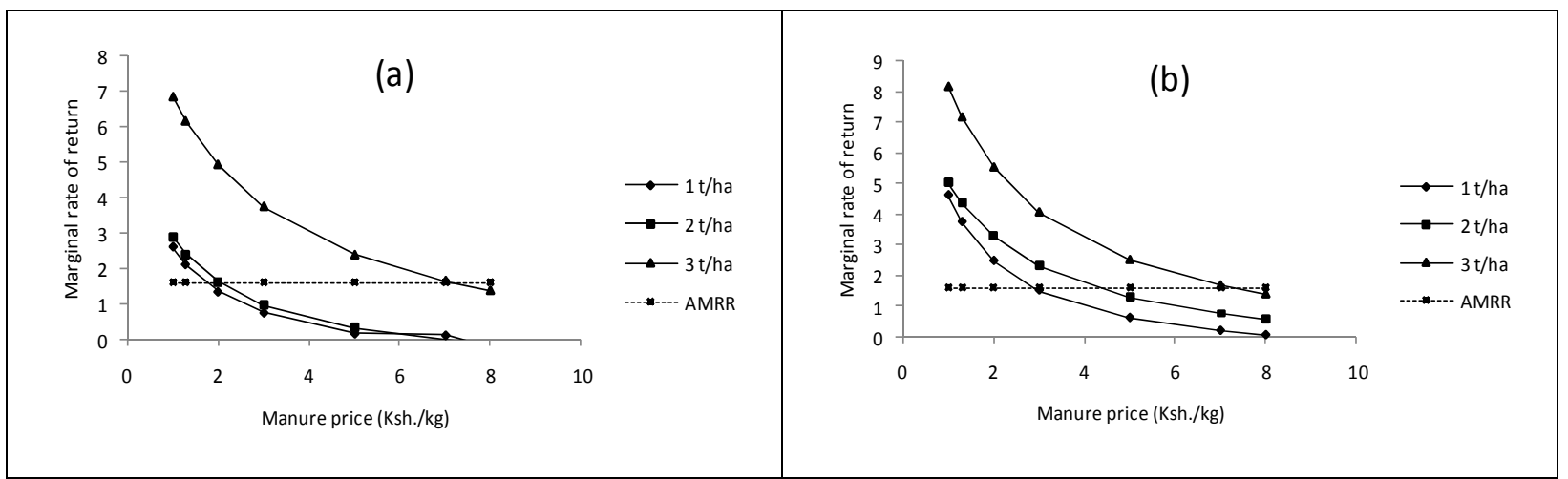

Figure 10. Effect of varying manure price on the marginal rate of return of grain amaranth in 2008 (a) and 2009

(b) 


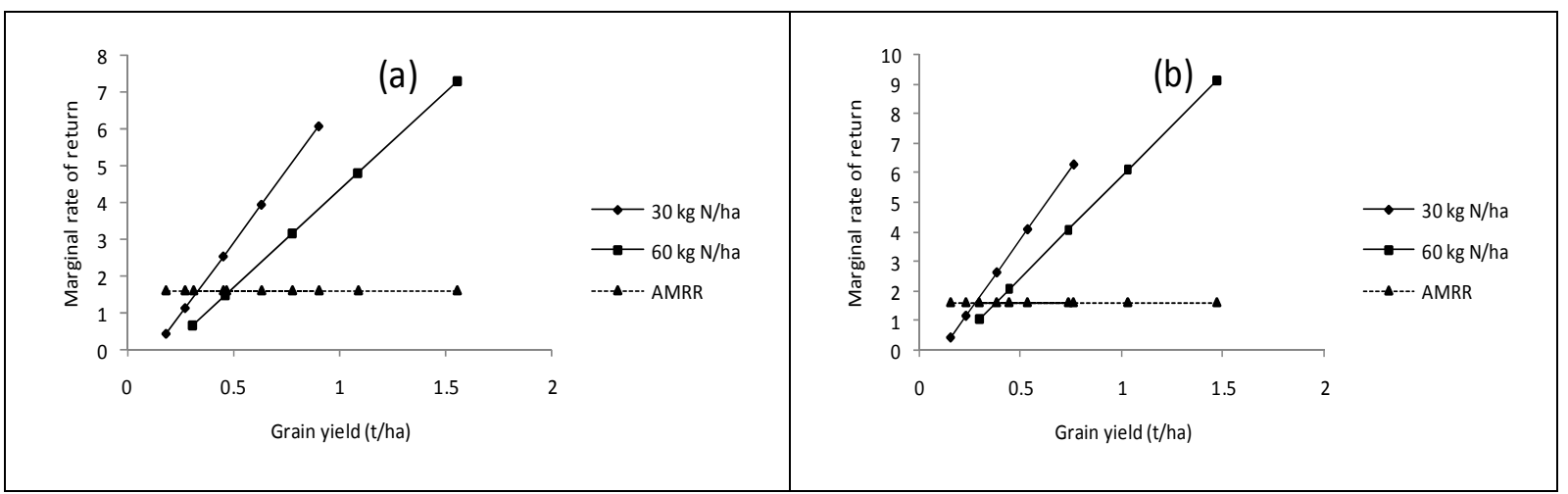

Figure 11. Effect of varying grain yield on the marginal rate of return of grain amaranth in 2008 (a) and 2009 (b)

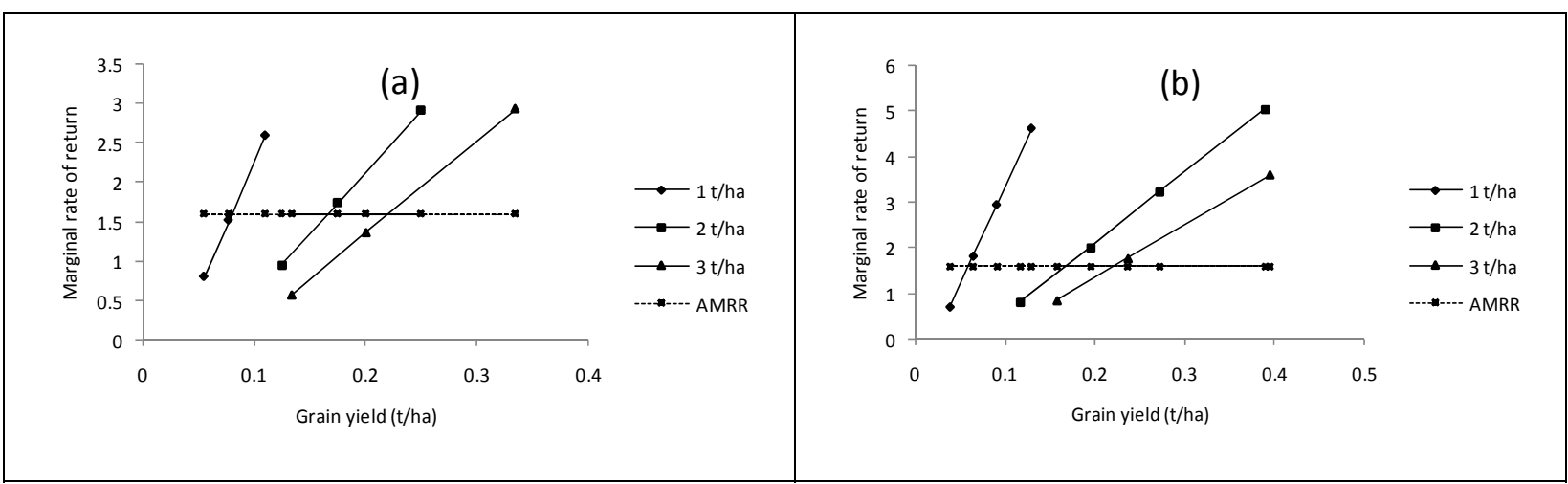

Figure 12. Effect of varying grain yield on the marginal rate of return of grain amaranth in 2008 (a) and 2009 (b) 